\title{
Zinc chemical forms and organic acid exudation in non-heading Chinese cabbages under zinc stress
}

\author{
Xiaoyun Li, Xiuling Chen, Xiumin Cui* \\ College of Resources and Environment, Shandong Agricultural University, Taian, China; \\ *Corresponding Author: xiumincui@sdau.edu.cn
}

Received 3 March 2012; revised 9 April 2012; accepted 16 May 2012

\begin{abstract}
As an essential element, zinc also is a heavy metal. Non-heading Chinese cabbage showed obvious tolerance to $\mathrm{Zn}$ stress in former research. To further understand the mechanisms involved in $\mathrm{Zn}$ adaptability and detoxification, two genotypes Suzhouqing and Aijiaohuang were selected to investigate the chemical forms of $\mathrm{Zn}$ and root exudation. Zinc stress obvious strained the plant growth, and Aijiaohuang was more injured than Suhouqing under $Z n$ stress. Under normal $\mathrm{Zn}$ levels, the chemical forms of $\mathrm{Zn}$ were diverse in three organs between genotypes. Results showed extractions of $2 \%$ HAc, $80 \%$ ethanol and $1 \mathrm{M} \mathrm{NaCl}$ were separately dominant in roots, petioles and leaves. However, under $\mathrm{Zn}$ stress $\left(13 \mathrm{mg} \cdot \mathrm{L}^{-1}\right.$ and $52 \mathrm{mg} \cdot \mathrm{L}^{-1}$ ) most of the $\mathrm{Zn}$ was extracted by $1 \mathrm{M} \mathrm{NaCl}$, and the subdominant amount of $\mathrm{Zn}$ was extracted by $80 \%$ ethanol. In the control only four types of organic acid could be detected. While under $\mathrm{Zn}$ stress, oxalic acid, tartaric acid, malic acid, lactic acid, acetic acid, citric acid and amber acid were all detected, so it could be speculated $\mathrm{Zn}$ detoxification with organic ligands or integrated with pectates and proteins in cells might be responsible for the adaptation of $\mathrm{Zn}$ stress in Chinese cabbage.
\end{abstract}

Keywords: Non-Heading Chinese Cabbages; Zn Stress; Chemical Forms; Root Exudation

\section{INTRODUCTION}

Non-heading Chinese cabbge (Brassica campestris ssp. chinensis Makino), is one of the most popular leaf vegetables, widely cultivated in north and south China. As an essential element, zinc is also a heavy metal. In recent years, unreasonable emissions of zinc galvanized Industrial waste, such as zinc mining, smelting and processing which led to extraordinary accumulation of zinc in the soil. Zinc in contaminated soil was easily absorbed by plants, which easily caused zinc toxicity. Subsequently, agricultural products may be contaminated and through the food chain human health will be threatened [1-3]. Heavy metal pollution has caused worldwide concern. This program was to investigate chemical form of zinc and the root exudation in non-heading Chinese cabbage under $\mathrm{Zn}$ stress, which provides some theoretical evidence for $\mathrm{Zn}$ tolerance mechanisms in plants.

\section{MATERIALS AND METHODS}

\subsection{Plants Materials}

The experiments were carried out in hydroponic trial. Two genotypes Suzhouqing and Aijiaohuang were selected as plant materials. The seeds were sterilized by $0.3 \% \mathrm{NaClO}$ for $10 \mathrm{~min}$, washed by ditilled water $\mathrm{H}_{2} \mathrm{O}$ and germinated at $25^{\circ} \mathrm{C}$. The germinating seeds were then sown in vermiculite. After sprouting, the seedlings were irrigated by half-strength nutrient solution.

When the seedlings grew to five true leaves, the most uniform and healthy seedlings were chosen to transport into plastic pots, covered by $3 \mathrm{~cm}$ thick foam. A week later, the seedlings were supplied with Hoagland nutrient solution, which was renewed every two days.

After pre-cultivation for one week, the seedlings were treated with $\mathrm{Zn}$ stress. $\mathrm{Zn}^{2+}\left(\mathrm{ZnSO}_{4} \cdot 7 \mathrm{H}_{2} \mathrm{O}\right)$ concentration was $0.43 \mathrm{mg} \cdot \mathrm{L}^{-1}$ (normal level), $13 \mathrm{mg} \cdot \mathrm{L}^{-1}$ (mildly stress), $52 \mathrm{mg} \cdot \mathrm{L}^{-1}$ (highly stress), recorded as $\mathrm{CK}, \mathrm{Zn} 1$, $\mathrm{Zn} 2$. The experiments were arranged in a randomized block design with three replicates. The $\mathrm{pH}$ of nutrient solution was then adjusted to $5.5 \pm 0.2$ with $\mathrm{KOH}$ or $\mathrm{HCl}$ (low concentration). During the period, the enviromental conditions $32 / 15^{\circ} \mathrm{C}$ (day/night) with a $12: 12 \mathrm{~h}$ (light: dark). Treated with $\mathrm{Zn}$ stress for 12 days, the plants were harvested for analysis.

\subsection{Chemical Forms Extraction}

To determine chemical forms of $\mathrm{Zn}$ in Chinese cabbage, the experiment was carried out by designated solu- 
tion in the following order [3,4]: 1) $80 \%$ ethanol, extracting inorganic $\mathrm{Zn}$ giving priority to nitrate/nitrite, chloride, and aminophenol $\mathrm{Zn}$. 2) Dual distilled water $\left(\mathrm{ddH}_{2} \mathrm{O}\right)$, extracting water soluble $\mathrm{Zn}$-organic acid complexes and $\mathrm{Zn}\left(\mathrm{H}_{2} \mathrm{PO}_{4}\right)_{2}$. 3) $1.0 \mathrm{~mol} \cdot \mathrm{L}^{-1} \mathrm{NaCl}$, extracting pectates and protein integrated $\mathrm{Zn}$. 4) $2 \%$ acetic acid (HAC), extracting undissolved zinc phosphate including $\mathrm{ZnHPO}_{4}$ and $\mathrm{Zn}_{3}\left(\mathrm{PO}_{4}\right)_{2}$ and other $\mathrm{Zn}$-phosphate complexes. 5) $0.6 \mathrm{~mol} \cdot \mathrm{L}^{-1} \mathrm{HCl}$, extracting zinc oxalate. The above extractants were recorded respectively as: $\mathrm{F}_{\mathrm{E}}, \mathrm{F}_{\mathrm{H} 2 \mathrm{O}}$, $\mathrm{F}_{\mathrm{NaCl}}, \mathrm{F}_{\mathrm{HAC}}, \mathrm{F}_{\mathrm{HCl}}$.

Fresh tissues were homogenized in extraction solution with a mortar and a pestle, diluted at the ratio of 1:100 $(\mathrm{w} / \mathrm{v})$, and vibrating for 22 hours at $25^{\circ} \mathrm{C}$. Afterwards the homogenate was centrifuged at $5000 \mathrm{~g}$ for $10 \mathrm{~min}$, obtaining the first supernatant solution in a conical beaker. The sedimentation was suspended twice in extraction solution and shaken for two hours at $25^{\circ} \mathrm{C}$, centrifuged at $5000 \mathrm{~g}$ for 10 minutes. Then pooled the supernatant of the three suspending and centrifuge steps for each of the five extraction solutions. The residue was recorded as $F_{R}$., and each of the pooled supernatant solutions were then evaporated on an electric plate at $70^{\circ} \mathrm{C}$ to constant weight. The above six parts were then digested at $145^{\circ} \mathrm{C}$ with an acid oxidative mixture of $\mathrm{HNO}_{3}: \mathrm{HClO}_{4}(2: 1, \mathrm{v} / \mathrm{v})$. Atomic absorption spectrometry (AA $370 \mathrm{MC}$ ) were used to test $\mathrm{Zn}$ content.

\subsection{Root Exudates Collection}

Root exudates were collected as described by Rengel [5]: The roots were first rapidly washed with $\mathrm{ddH}_{2} \mathrm{O}$ to remove the surface adhesion from nutrient solution. The

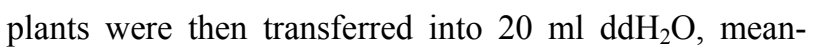
while all the roots should be assured to submerge in the water. After four hours the whole plants were moved away, and some thymols were added to the remaining solutions (to cease the activity of microorganism), and then condensed to $5 \mathrm{ml}$ by a vacuum rotary evaporator at $40^{\circ} \mathrm{C}$.

The organic acids were analyzed using High Performance Liquid Chromatography (HPLC). The samples were filtered through $0.45 \mu \mathrm{m}$ membrane to remove impurities.
The chromatograph conditions were as followed: mobile phase $\mathrm{KH}_{2} \mathrm{PO}_{4}$, flow rate $0.9 \mathrm{ml} \cdot \mathrm{min}^{-1}$, detection wavelength $213 \mathrm{~nm}$, sensitivity 0.8 , manual injection volume $10 \mu \mathrm{l}$. The target time for the standard solutions (from Sigma Company) was 20 minutes, and 50 minutes for the exudate samples.

Least significant difference (LSD) was used for multiple comparisons between different treatment means.

\section{RESULTS AND ANALYSIS}

As a trace element, excessive $\mathrm{Zn}$ in media would lead to phytotoxicity. After Zn stress for 12 days, Suzhouqing and Aijiaohuang showed signs of chlorisis, and were withered along the leaf margin, although still alive. Seen from Table 1, $\mathrm{Zn}$ stress restrained the plant growth, and obviously decreased the biomass of leaves, petioles and roots. Compared with CK, the shoot biomass of Suzhouqing and Aijiaohuang (including the leaves and petioles) decreased $44.4 \%$ and $59.0 \%$ respectively under $\mathrm{Zn} 1$ stress. The root biomass of Suzhouqing was remarkablely higher than that of Aijiaohuang, compared with CK, Suzhouqing and Aijiaohuang respectively decreased 44.4\% and $52.63 \%$ under $\mathrm{Zn} 1$ stress. Under $\mathrm{Zn} 2$ stress, the toxicity symptoms were much more visible, and the total biomass of Suzhouqing and Aijiaohuang reduced $66.5 \%$ and $84.8 \%$, which indicated Aijiaohuang had sustained more injury under higher $\mathrm{Zn}$ stress.

\subsection{The Zn Chemical Forms in Plants under Zn Stress}

As Table 2 showed, $\mathrm{Zn}$ content extracted by different extractants were markedly diverse in different organs. Zinc stress led to zinc content obviously rise in nonheading Chinese cabbage. The $\mathrm{Zn}$ form extracted by $\mathrm{NaCl}$ was predominant in leaves, stems and roots.

In leaves of Suzhouqing, the $\mathrm{Zn}$ form extracted by $\mathrm{NaCl}$ were increased from $1.90 \mathrm{mg} \cdot \mathrm{kg}^{-1}$ (CK) to 42.43 $\mathrm{mg} \cdot \mathrm{kg}^{-1}(\mathrm{Zn} 2)$, almost up to 20 times. The following chemical form was extracted by $80 \%$ ethanol, the highest concentration under CK level. Then the extraction of $\mathrm{H}_{2} \mathrm{O}$, was much higher than $\mathrm{F}_{\mathrm{HAC}}, \mathrm{F}_{\mathrm{R}}, \mathrm{F}_{\mathrm{HCl}}$, which were

Table 1. The biomass of non-heading Chinese cabbage under zinc stress (mg plant $\left.{ }^{-1}, \mathrm{DW}\right)$.

\begin{tabular}{|c|c|c|c|c|c|}
\hline Genotypes & Treatments & Roots & Petioles & Leaves & Total \\
\hline \multirow{3}{*}{ Suzhouqing } & $\mathrm{CK}$ & $270 \pm 28 a$ & $1110 \pm 80 \mathrm{a}$ & $1140 \pm 98 \mathrm{a}$ & 2510 \\
\hline & $\mathrm{Zn} 1$ & $150 \pm 16 b$ & $550 \pm 58 b$ & $690 \pm 80 b$ & 1390 \\
\hline & $\mathrm{Zn} 2$ & $60 \pm 13 c$ & $330 \pm 71 c$ & $450 \pm 68 c$ & 840 \\
\hline \multirow{3}{*}{ Aijiaohuang } & $\mathrm{CK}$ & $190 \pm 22 \mathrm{a}$ & $1250 \pm 89 a$ & $1650 \pm 104 \mathrm{a}$ & 3090 \\
\hline & $\mathrm{Zn} 1$ & $90 \pm 9.0 \mathrm{~b}$ & $550 \pm 68 b$ & $640 \pm 100 \mathrm{~b}$ & 1280 \\
\hline & $\mathrm{Zn} 2$ & $20 \pm 5.0 \mathrm{c}$ & $180 \pm 31 \mathrm{c}$ & $270 \pm 67 c$ & 470 \\
\hline
\end{tabular}

Note: Data followed by different letters in the same row are significant at $5 \%$ levels. 
Table 2. The chemical forms of $\mathrm{Zn}$ in non-heading Chinese cabbage under $\mathrm{Zn}$ stress $\left(\mathrm{mg} \cdot \mathrm{kg}^{-1}\right)$.

\begin{tabular}{|c|c|c|c|c|c|c|c|c|c|}
\hline \multirow{2}{*}{ Genotyes } & \multirow{2}{*}{ Organs } & \multirow{2}{*}{ Treatments } & \multicolumn{6}{|c|}{ Zn content } & \multirow{2}{*}{$\begin{array}{c}\text { Total } \\
\text { content }\end{array}$} \\
\hline & & & $\mathrm{F}_{\mathrm{E}}$ & $\mathrm{F}_{\mathrm{W}}$ & $\mathrm{F}_{\mathrm{NaCl}}$ & $\mathrm{F}_{\mathrm{HAC}}$ & $\mathrm{F}_{\mathrm{HCl}}$ & $\mathrm{F}_{\mathrm{R}}$ & \\
\hline \multirow{9}{*}{ Suzhouqing } & \multirow{3}{*}{ Leaves } & $\mathrm{CK}$ & $16.63 \pm 0.58 \mathrm{c}$ & $12.89 \pm 1.79 \mathrm{c}$ & $1.90 \pm 0.57 \mathrm{c}$ & $5.93 \pm 1.36 \mathrm{~cd}$ & $6.88 \pm 0.78 \mathrm{c}$ & $2.89 \pm 0.24 \mathrm{c}$ & 47.12 \\
\hline & & $\mathrm{Zn} 1$ & $32.88 \pm 1.20 \mathrm{~b}$ & $21.40 \pm 1.54 b$ & $38.76 \pm 2.09 \mathrm{~b}$ & $13.15 \pm 1.54 \mathrm{a}$ & $9.77 \pm 0.87 \mathrm{a}$ & $3.83 \pm 0.22 \mathrm{a}$ & 119.80 \\
\hline & & $\mathrm{Zn} 2$ & $35.29 \pm 0.78 \mathrm{a}$ & $19.35 \pm 1.13 b$ & $42.43 \pm 1.73 b$ & $7.05 \pm 0.91 \mathrm{c}$ & $8.51 \pm 0.94 b$ & $3.51 \pm 0.13 b$ & 116.14 \\
\hline & \multirow{3}{*}{ Petioles } & $\mathrm{CK}$ & $8.66 \pm 1.43 \mathrm{~d}$ & $5.60 \pm 0.98 \mathrm{~d}$ & $22.86 \pm 1.11 \mathrm{c}$ & $1.13 \pm 0.21 \mathrm{e}$ & $1.08 \pm 0.15 \mathrm{~d}$ & $1.59 \pm 0.09 \mathrm{c}$ & 40.92 \\
\hline & & $\mathrm{Zn} 1$ & $21.37 \pm 1.09 b$ & $22.13 \pm 1.10 \mathrm{c}$ & $65.47 \pm 1.15 b$ & $10.29 \pm 1.21 \mathrm{~cd}$ & $1.65 \pm 0.29 \mathrm{c}$ & $2.24 \pm 0.10 \mathrm{~b}$ & 123.15 \\
\hline & & $\mathrm{Zn} 2$ & $30.75 \pm 0.47 \mathrm{a}$ & $29.16 \pm 1.20 \mathrm{~b}$ & $93.79 \pm 1.91 \mathrm{a}$ & $27.47 \pm 1.97 \mathrm{~b}$ & $4.84 \pm 0.21 b$ & $2.67 \pm 0.26 \mathrm{a}$ & 188.68 \\
\hline & \multirow{3}{*}{ Roots } & CK & $16.91 \pm 0.62 \mathrm{~d}$ & $6.82 \pm 1.13 \mathrm{~d}$ & $11.07 \pm 1.40 \mathrm{~d}$ & $25.92 \pm 1.16 c$ & $13.07 \pm 1.66 \mathrm{c}$ & $4.57 \pm 0.66 c$ & 78.36 \\
\hline & & $\mathrm{Zn} 1$ & $31.14 \pm 0.63 b$ & $30.88 \pm 0.92 \mathrm{c}$ & $83.53 \pm 1.69 \mathrm{c}$ & $48.16 \pm 2.49 b$ & $34.47 \pm 1.57 b$ & $10.30 \pm 1.09 \mathrm{~b}$ & 238.47 \\
\hline & & $\mathrm{Zn} 2$ & $45.50 \pm 1.07 \mathrm{a}$ & $57.22 \pm 1.65 b$ & $193.2 \pm 7.54 b$ & $85.73 \pm 3.51 \mathrm{a}$ & $61.22 \pm 2.59 a$ & $23.97 \pm 1.66 \mathrm{a}$ & 466.88 \\
\hline \multirow{9}{*}{ Aijiaohuang } & \multirow{3}{*}{ Leaves } & $\mathrm{CK}$ & $15.42 \pm 1.63 \mathrm{c}$ & $6.89 \pm 0.82 \mathrm{~d}$ & $4.19 \pm 1.02 \mathrm{c}$ & $2.41 \pm 0.35 \mathrm{e}$ & $6.84 \pm 0.30 \mathrm{c}$ & $2.28 \pm 0.16 \mathrm{~d}$ & 38.02 \\
\hline & & $\mathrm{Zn} 1$ & $31.84 \pm 0.20 b$ & $20.26 \pm 1.24 b$ & $42.51 \pm 1.67 b$ & $3.71 \pm 0.58 \mathrm{de}$ & $2.94 \pm 0.40 \mathrm{~d}$ & $2.98 \pm 0.13 c$ & 104.24 \\
\hline & & $\mathrm{Zn} 2$ & $36.01 \pm 1.02 \mathrm{a}$ & $30.34 \pm 2.10 \mathrm{a}$ & $69.48 \pm 1.37 \mathrm{a}$ & $9.52 \pm 1.25 b$ & $1.66 \pm 0.37 \mathrm{e}$ & $3.36 \pm 0.15 b$ & 150.37 \\
\hline & \multirow{3}{*}{ Petioles } & $\mathrm{CK}$ & $8.09 \pm 1.81 \mathrm{~d}$ & $6.03 \pm 0.93 \mathrm{~d}$ & $13.98 \pm 1.33 \mathrm{c}$ & $7.58 \pm 0.77 d$ & $1.77 \pm 0.25 \mathrm{c}$ & $1.24 \pm 0.09 \mathrm{~d}$ & 38.69 \\
\hline & & $\mathrm{Zn} 1$ & $18.60 \pm 1.81 \mathrm{c}$ & $22.77 \pm 1.59 \mathrm{c}$ & $65.09 \pm 2.80 \mathrm{~b}$ & $10.91 \pm 0.91 \mathrm{c}$ & $1.96 \pm 0.27 \mathrm{c}$ & $2.19 \pm 0.09 \mathrm{~b}$ & 121.53 \\
\hline & & $\mathrm{Zn} 2$ & $31.24 \pm 1.58 \mathrm{a}$ & $33.64 \pm 0.66 \mathrm{a}$ & $98.16 \pm 2.35 \mathrm{a}$ & $31.64 \pm 1.54 \mathrm{a}$ & $6.21 \pm 0.56 \mathrm{a}$ & $2.73 \pm 0.25 \mathrm{a}$ & 203.62 \\
\hline & \multirow{3}{*}{ Roots } & $\mathrm{CK}$ & $13.18 \pm 0.47 \mathrm{e}$ & $7.06 \pm 1.50 \mathrm{~d}$ & $8.48 \pm 1.81 \mathrm{~d}$ & $23.74 \pm 2.60 \mathrm{c}$ & $12.44 \pm 0.69 c$ & $4.79 \pm 0.22 \mathrm{c}$ & 69.69 \\
\hline & & $\mathrm{Zn} 1$ & $24.36 \pm 1.71 \mathrm{c}$ & $31.59 \pm 1.03 \mathrm{c}$ & $70.68 \pm 3.11 \mathrm{c}$ & $46.08 \pm 0.80 \mathrm{~b}$ & $36.94 \pm 1.26 \mathrm{~b}$ & $10.94 \pm 0.48 b$ & 220.59 \\
\hline & & $\mathrm{Zn} 2$ & $11.97 \pm 1.67 \mathrm{e}$ & $70.16 \pm 1.55 a$ & $215.61 \pm 3.95 \mathrm{a}$ & $92.79 \pm 1.17 \mathrm{a}$ & $57.24 \pm 2.67 \mathrm{a}$ & $24.93 \pm 1.70 \mathrm{a}$ & 472.70 \\
\hline
\end{tabular}

Note: Data followed by different letters in the same row are significant at $5 \%$ levels.

rather low. Under control conditions, $\mathrm{Zn}$ forms extracted by $80 \%$ ethanol and $\mathrm{ddH}_{2} \mathrm{O}$ were the predominant, respectively representing $35.30 \%$ and $27.35 \%$ of the total amount. Under $\mathrm{Zn}$ stress, the $\mathrm{Zn}$ form extracted by $\mathrm{NaCl}$ and $80 \%$ ethanol were predominant form.

In petioles of Suzhouqing, the extraction of $1 \mathrm{M} \mathrm{NaCl}$ was always much higher than other forms regardless of stress. As followed was extraction of $80 \%$ ethanol, $\mathrm{ddH}_{2} \mathrm{O}$, and $2 \% \mathrm{HAc}$. Zinc stress made the above four chemicals sharply increase, and the other forms ranged a little. Most forms in petioles that were extracted by $\mathrm{NaCl}$ and ethanol, accounted for $55.87 \%$ and $21.16 \%$ of the total amount respectively.

In roots of Suzhouqing, $\mathrm{Zn}$ form extracted by $1 \mathrm{M}$ $\mathrm{NaCl}$ were increased from $11.07 \mathrm{mg} \cdot \mathrm{kg}^{-1}$ (CK) to 193.2 $\mathrm{mg} \cdot \mathrm{kg}^{-1}$ (Zn2), almost up to 18 times. As followed was extracted by $2 \% \mathrm{HAc}$, the highest concentration at $\mathrm{CK}$ level, increased three times under $\mathrm{Zn} 2$ stress. The most diverse form was extraction of $1 \mathrm{M} \mathrm{NaCl}$, the following was extraction of $\mathrm{ddH}_{2} \mathrm{O}$, which were more sensitive to $\mathrm{Zn}$ stress. This indicated that they might play more important role in tolerance faced $\mathrm{Zn}$ stress. Differently from the aboveground, under CK level in roots extraction of $2 \%$ HAc was the highest, then extraction of $80 \%$ ethanol, and accounted for $33.08 \%$ and $21.58 \%$ of the total amount.

Zinc stress enabled the roots to take up and accumu- late much more $\mathrm{Zn}$ than the leaves and petioles. The similar trend was obtained in Aijiaohuang.

\subsection{The Organic Acids in Root Exudates of Non-Heading Chinese Cabbage under Zn Stress}

Seven types of low molecular weight organic acids were detected in this trial: oxalic acid, tartaric acid, succinic acid, malic acid, citric acid, acetic acid and lactic acid. The secretion of each plant ranged from $569.3 \mu \mathrm{g}$ to $1709 \mu \mathrm{g}$. Under the control level, four kinds of organic acids were detected in Suzhouqing: oxalic acid, tartaric acid, malic acid and succinic acid. Among them, the oxalic acid was the most, followed the tartaric acid and malic acid, succinic acid the least. Similarly, also four types of organic acids were detected in Aijiaohuang, different from the former, malic acid replaced of lactic acid (Table 3).

Under the different degree of $\mathrm{Zn}$ stress for 12 days, the composition and content of organic acids changed. Compared with the control, Zn1stress enhanced two kinds of organic acids (acetic acid and citric acid) in Suzhouqing, however, the total content of organic acids detected decreased by $50.32 \%$. Under $\mathrm{Zn} 2$ stress, seven types of organic acids could be detected but the total amount of the organic acids increased by $49.15 \%$. For Aijiaohuang, only four organic acids were identified in control, while 
Table 3. The organic acid exudated in non-heading Chinese cabbage under Zn stress (ug $\cdot$ plant $^{-1}$ ).

\begin{tabular}{ccccccc}
\hline \multirow{2}{*}{ Organic acid } & \multicolumn{3}{c}{ Suzhouqing } & \multicolumn{3}{c}{ Aijiaohuang } \\
\cline { 2 - 7 } & CK & Zn1 & Zn2 & CK & Zn1 & Zn2 \\
\hline Oxalic acid & 546.9 & 344.2 & 645.5 & 363.9 & 177.9 & 275.9 \\
Tartaric acid & 398.9 & 60.38 & 286.7 & 188.8 & 106.1 & 117.5 \\
Malic acid & 158.6 & 52.03 & 174.9 & - & 94.24 & 57.55 \\
Lactic acid & - & - & 242.2 & 219.5 & 359.1 & 54.75 \\
Acetic acid & - & 77.39 & 181.7 & - & 95.64 & 75.39 \\
Citric acid & - & 26.04 & 127.7 & - & 74.81 & 39.32 \\
Amber acid & 41.15 & 9.18 & 50.22 & 48.60 & 115.0 & 22.81 \\
Total content & 1146 & 569.2 & 1708 & 820.7 & 1023 & 643.3 \\
\hline
\end{tabular}

- means undetectable.

under $\mathrm{Zn} 1$ and $\mathrm{Zn} 2$ stress, the other three types like malic acid, citric acid and acetic acid could even be detected. The total amount of organic acids under Zn1 stress were increased by $24.61 \%$ than the control, however they reduced by $21.63 \%$ at $\mathrm{Zn} 2$ level.

\section{DISCUSSION}

Though the biomass of non-heading Chinese cabbage was decreased by $\mathrm{Zn}$ stress, they were still alive, which indicates some tolerant mechanism is produced. Chemical speciation of heavy metals is closely related to their biological function, and different chemical forms of $\mathrm{Zn}$ extracted by different designated extraction solutions have distinct toxicity degrees and migration of $\mathrm{Zn}$. For instance, inorganic and organic water-soluble $\mathrm{Zn}$ (extracted by $80 \%$ ethanol and $\mathrm{ddH}_{2} \mathrm{O}$, respectively), with higher capacity to migrate, is more deleterious to plant cells than the undissolved $\mathrm{Zn}$ phosphate (extracted by $2 \% \mathrm{HAc}$ ) and zinc oxalate (extracted by $0.6 \mathrm{M} \mathrm{HCl}$ ) [6]. Meanwhile, for plants containing high concentration of $\mathrm{Zn}$ that showed no or little toxicity, $\mathrm{Zn}$ should be in a chemical form that causes low or no phytotoxicity $[7,8]$. In our study, $\mathrm{Zn}$ existed in different chemical forms among different organs.

Under control conditions the Zn form extracted by ethanol in leaves has the highest concentration, followed by $\mathrm{NaCl}$ in petioles and by HAc in root (Table 1). The majority of $\mathrm{Zn}$ was in inorganic form suggesting high capacity to be transported to leaves (Table 2), most Zn was integrated with pectates and protein (extracted by 1 $\mathrm{M} \mathrm{NaCl}$ ) in petioles, in roots the majority of $\mathrm{Zn}$ was not dissolved $\mathrm{Zn}$ phosphate and other Zn-phosphate complexes.

$\mathrm{Zn}$ was hypothesized to be chelated by some specific polar material, such as hydroxyl or carboxyl, to form a non-toxic complex under $\mathrm{Zn}$ stress. It may also be assumed that higher concentration and larger percentages of $\mathrm{NaCl}$-extractable $\mathrm{Zn}$ in organs were responsible for the adaptation of Chinese cabbage to $\mathrm{Zn}$ stress, which stands for the point of view that compartmentation of vacuolar and sequestration in cell wall may be crucial for the detoxification of $\mathrm{Zn}$ and thus tolerance to metal stress [4].

Exudating organic compounds to the external environment was an adaptive response in plants. Under heavy metal stress, plant roots promote the secretion of citric acid, succinic acid, malic acid and other organic acids to alleviate heavy metal toxicity $[9,10]$. Under Al stress, buckwheat roots secreted large amounts of oxalic acid and combined with $\mathrm{Al}^{3+}$ to form oxalic acid aluminum compound to reduce the Al toxicity on roots [11]. Furthermore under $\mathrm{Zn}$ stress, different genotypic Chinese cabbage released oxalic acid, tartaric acid, malic acid and other organic acids respectively [12]. The above results indicated that the non-heading Chinese cabbage under $\mathrm{Zn}$ stress secreted more oxalic acid, tartaric acid, malic acid, lactic acid, acetic acid, citric acid and succinic acid than the control. The variety of organic acid between Suzhouqing and Aijiaohuang were mainly citric acid, malic acid, acetic acid and lactic acid, which perhaps was one of the reasons that $\mathrm{Zn}$ absorption and tolerance varied significantly.

Organic acids could ligate metal ion into chelate complex, and participate compartment in vacuole in order to reduce excessive ion toxicity. Under $\mathrm{Zn}$ stress, plant secretions of large quantities of organic acids was one of the resistance mechanisms [7,13]. Therefore, we speculated that similar mechanism also existed in non-heading Chinese cabbage.

\section{ACKNOWLEDGEMENTS}

This work was supported by Sci-Tech Development Project of Taian city (32606) and China Agriculture Research System (CARS-25-D).

\section{REFERENCES}

[1] Bi, X.Y., Feng, X.B., Yang,Y.G., Qiu, G., Li, G., Li, F., Liu, T., Fu, Z. and Jin, Z. (2006) Environmental contamination of heavy metals from zinc smelting areas in Hezhang County, western Guizhou, China. Environment Interna- 
tional, 32, 883-890. doi:10.1016/j.envint.2006.05.010

[2] Broadley, M.R., White, P.J., Hammond, J.P., Zelko, I. and Lux, A. (2007). Zinc in plants. New Phytologist, 173, 677-702. doi:10.1111/j.1469-8137.2007.01996.x

[3] Zhou, S.B., Xu, L.S., Wu, L.H., Li, Y.M., Li, N. and Cui, L.Q. (2008) Subcellular distribution and chemical forms of $\mathrm{Cd}$ and $\mathrm{Zn}$ in Sedum jinianu. Chinese Journal of Applied Ecology, 19, 2515-2520.

[4] Fu, X.P., Dou, C.M., Chen, Y.X., Chen, X.C., Sh, J.Y. and Yu, M.G. (2011) Subcellular distribution and chemical forms of cadmium in Phytolacca americana L. Journal of Hazardous Materials, 186, 103-107. doi:10.1016/i.jhazmat.2010.10.122

[5] Rengel, Z., Romheld, V. and Marschner, H. (1998) Uptake of zinc and iron by wheat genotypes differing in tolerance to zinc efficiency. Journal of Plant Physiology, 152, 433-438. doi:10.1016/S0176-1617(98)80260-5

[6] Wu, Q., Du, S.J., Zeng, X.W., Fang, X.H., Yu, F.M. and Qiu, R.L. (2006) Subcellular distribution and chemical forms of Potentilla grifithii Hook. Ecology and Environment, 15, 40-44.

[7] Chen, Y.X. (2008) Plant contaminated chemistry of heavy metal in soil. Science China Press, Beijing.

[8] Calhôa, C.F., Monteiro, M.S., Soares, A.M. and Mann,
R.M. (2011) The influence of metal speciation on the bioavailability and sub-cellular distribution of cadmium to the terrestrial isopod, Porcellio dilatatus. Chemosphere, 83, 531-537. doi:10.1016/j.chemosphere.2010.12.055

[9] Pellet, D.M., Papemik, L.A. and Kochian, L.V. (1996) Multiple aluminum resistance mechanisms in wheat, the roles of root apical phosphate and malate exudation. Plant Physiology, 112, 591-597.

[10] Jones, D.L. (1998). Organic acids in the rhizosphere-A critical review. Plant and Soil, 205, 25-44. doi:10.1023/A:1004356007312

[11] Ma, J.F., Zheng, S.J. and Matsumoto, H. (1997) Specific secretion of citric acid induced by Al stress in Cassia tora L. Plant and Cell Physiology, 38, 1019-1025. doi:10.1093/oxfordjournals.pcp.a029266

[12] Xu, W.H., Liu, J.Z., Huang, H. and Xiong, Z.T. (2006) Study of Zn stress on plant growth, Zn uptake and root exudates in different cultivars of Chinese cabbage. Chinese Agricultural Science Bulletin, 22, 458-463.

[13] Lombi, E., Zhao, F.J., Dunham, S.J. and McGrath, S.P. (2000) Cadmium accumulation in populations of Thlaspi caerulescens and Thlaspi goesingense. New Phytologist, 145, 11-20. doi:10.1046/j.1469-8137.2000.00560.x 